\title{
SOSIALISASI PEMBUATAN HAND SANITIZER EKSTRAK LIDAH BUAYA DI DESA BUNUT WETAN KECAMATAN PAKIS
}

\author{
Hanjar Ikrima Nanda*1, Nanda Trisnawan ${ }^{2}$, Inka Prananda Putri ${ }^{3}$, Adhitya Dwi Permana ${ }^{4}$ \\ $1,2,3,4$ Universitas Negeri Malang \\ *e-mail: hanjar.ikrima.fe@um.ac.id¹', nanda.trisnawan.1803316@students.um.ac.id², \\ inka.prananda.1803516@students.um.ac.id ${ }^{3}$, adhitya.dwi.1805116@students.um.ac.id ${ }^{3}$
}

\begin{abstract}
Abstrak
Pada masa pandemi diperlukan tindakan preventif untuk menghindari penularan virus Corona. Salah satu tindakan tersebut yaitu penggunaan hand sanitizer untuk menjaga kebersihan tangan. Tim KKN Universitas Negeri Malang mengadakan sosialisasi pembuatan hand sanitizer ekstrak lidah buaya. Tujuan dari kegiatan ini sebagai upaya dalam memberikan edukasi dan pelatihan pembuatan hand sanitizer dari bahan alami. Hand sanitizer yang terbuat dari bahan alami relatif lebih murah dan mudah didapatkan. Tahapan kegiatan yaitu wawancara terkait masalah yang ada di Desa Bunut Wetan, kemudian diskusi dan perizinan kepada pihak desa. Sosialisasi dilakukan kepada kader posyandu diawali dengan pemaparan materi, dilanjutkan praktek pembuatan hand sanitizer ekstrak lidah buaya dan pengisian angket. Berdasarkan hasil angket 95,83\% resoponden paham bahwa hand sanitizer dapat dibuat dari bahan alami, 88,54\% paham manfaat lidah buaya dalam pembuatan hand sanitizer, fungsi dari bahan pembuatan hand sanitizer dan cara pembuatan hand sanitizer ekstrak lidah buaya, $90,63 \%$ kader posyandu paham tentang manfaat hand sanitizer.
\end{abstract}

Kata kunci: Bunut Wetan, Hand sanitizer, Lidah buaya

\section{Abstrack}

During the pandemic, preventive measures are needed to avoid the transmission of the Corona virus. One of these actions is the use of hand sanitizers to maintain hand hygiene. The Malang State University Community Service Team held a socialization on the manufacture of aloe vera extract hand sanitizer. The purpose of this activity is to provide education and training on making hand sanitizers from natural ingredients. Hand sanitizers made from natural ingredients are relatively inexpensive and easy to obtain. The activity stages are interviews related to problems that exist in Bunut Wetan Village, then discussions and permits to the village. The socialization was carried out to posyandu cadres starting with the presentation of the material, followed by the practice of making aloe vera extract hand sanitizer and filling out questionnaires. Based on the results of the questionnaire, $95.83 \%$ of respondents understood that hand sanitizers can be made from natural ingredients, $88.54 \%$ understood the benefits of aloe vera in making hand sanitizers, the function of the ingredients for making hand sanitizers and how to make hand sanitizers with aloe vera extract, 90.63\% Posyandu cadres understand the benefits of hand sanitizers.

Kata kunci: Bunut Wetan, Hand sanitizer, Aloe vera

\section{PENDAHULUAN}

Adanya penyebaran virus Corona yang semakin meluas memberikan dampak yang besar bagi masyarakat, terutama perubahan di sektor sosial ekonomi. Masyarakat diharapkan dapat melakukan tindakan preventif untuk mencegah penularan virus Corona. Setiap orang 
mempunyai peranan penting untuk memutus rantai penularan virus. Beberapa tindakan preventif tersebut adalah memakai masker, mencuci tangan atau menggunakan hand sanitizer secara berkala, menjaga jarak, dan mengurangi kontak fisik. Meskipun masyarakat telah diedukasi untuk menerapkan tindakan tersebut, tidak sedikit masyarakat yang masih melanggar kebijakan tersebut.

Salah satu desa yang terletak di Kecamatan Pakis yaitu Desa Bunut Wetan telah memberikan arahan kepada masyarakat setempat untuk mematuhi protokol kesehatan. Namun kurangnya kesadaran masyarakat Bunut Wetan terkait penyebaran virus Corona mengakibatkan belum terlaksananya protokol kesehatan secara maksimal, seperti kegiatan mencuci tangan ataupun menggunakan hand sanitizer. Penggunaan hand sanitizer yang semakin meningkat juga menyebabkan harga hand sanitizer semakin langka dan mahal, sehingga masyarakat kurang berminat untuk menggunakan hand sanitizer.

Hand sanitizer yaitu bahan antiseptik yang digunakan untuk membersihkan tangan karena dapat menghambat tumbuhnya bakteri. Penggunaan hand sanitizer yaitu dengan menuangkan cairan hand sanitizer pada tangan kemudian digosok secara merata ke seluruh bagian permukaan tangan. Hand sanitizer memiliki kandungan bahan kimia dan alkohol dengan konsentrasi tinggi supaya efektif dalam menghambat pertumbuhan bakteri, namun jika hal tersebut dilakukan secara terus menerus maka dapat berbahaya bagi kulit. Sehingga diperlukan hand sanitizer yang terbuat dari bahan alami yang aman dan mudah didapatkan dengan harga terjangkau seperti hand sanitizer yang terbuat dari lidah buaya. Adanya inovasi dari bahan alam akan mengurangi bahan kimia dalam hand sanitizer tanpa mengurangi keefektifan dalam menghambat pertumbuhan bakteri (Fatimah \& Ardiani, 2018)

Lidah buaya merupakan salah satu tanaman yang memiliki banyak manfaat. Daging lidah buaya banyak dimanfaatkan dalam produk kosmetik dan makanan. Selain itu juga digunakan sebagai antiseptik, antiradang dan penutup luka (Susilo et al., 2013). Lidah buaya mengandung flavonoid, polifenol, saponin dan tanin sehingga bersifat antiseptik. Adanya kandungan vitamin A, E, antioksidan dapat melembabkan kulit (Harjowinangun et al., 2020). Lidah buaya bersifat antiseptik dikarenakan adanya efek sinergisme berbagai kandungan pada tanaman lidah buaya. Lidah buaya banyak ditanam oleh masyarakat dikarenakan tumbuhan tersebut mudah untuk dibudidayakan dan mudah untuk tumbuh. Namun masih sedikit masyarakat yang mengetahui bahwa ekstrak lidah buaya dapat digunakan sebagai bahan hand sanitizer.

Berdasarkan latar belakang permasalahan tersebut, diperlukan kegiatan sosialisasi pembuatan hand sanitizer kepada masyarakat Bunut Wetan. Upaya untuk memproduksi hand 
sanitizer dari bahan alami seperti lidah buaya dapat menjadi solusi terkait hand sanitizer yang semakin langka dan mahal. Hal tersebut dikarenakan alat dan bahan yang diperlukan dalam pembuatan hand sanitizer ekstrak lidah buaya mudah untuk didapatkan dengan harga yang terjangkau. Tujuan dari kegiatan sosialisasi tersebut yaitu mengedukasi masyarakat untuk bisa membuat hand sanitizer secara mandiri, mengedukasi masyarakat tentang pemanfaatan lidah buaya sebagai bahan hand sanitizer dan penerapan transfer ilmu dari lingkungan akademik ke masyarakat.

\section{METODE}

Sosialisasi pembuatan hand sanitizer ekstrak lidah buaya dilakukan oleh tim KKN Universitas Negeri Malang dengan sasaran kader-kader posyandu di Desa Bunut Wetan Kecamatan Pakis. Ada beberapa tahapan-tahapan sebelum dilakukan sosialisasi. Tahap pertama wawancara untuk mengidentifikasi masalah yang ada di Desa Bunut Wetan dengan kepala desa, sekretaris desa dan bidan desa. Tahap kedua persiapan program yang meliputi persiapan materi sosialisasi, praktik pembuatan hand sanitizer dan keperluan-keperluan lain untuk sosialisasi yang di lakukan di kampus Universitas Negeri Malang.

Pelaksanaan sosialisasi pembuatan hand sanitizer ekstrak lidah buaya dilakukan melalui beberapa sesi. Pada sesi pertama dipaparkan materi tentang hand sanitizer dan lidah buaya. Sesi kedua demonstrasi pembuatan hand sanitizer ekstrak lidah buaya yang kemudian diikuti oleh peserta. Sesi ketiga merupakan pengisian angket yang dilakukan untuk mengetahui tingkat pemahaman peserta.

Alat dan bahan yang digunakan dalam pembuatan hand sanitizer ekstrak lidah buaya: gelas ukur, batang pengaduk, corong, gelas plastik, pisau, blender, saringan, botol semprot, etanol $70 \%$, gliserol, lidah buaya, dan aroma lidah buaya. Langkah pembuatan hand sanitizer yaitu dengan menakar etanol $70 \%$ sebanyak $4,5 \mathrm{~mL}$, ditambahkan dengan $1,5 \mathrm{~mL}$ gliserol, setelah itu ditambahkan 3,5 mL ektrak lidah buaya kemudian diaduk hingga homogen dan ditambahkan tiga tetes aroma lidah buaya. 


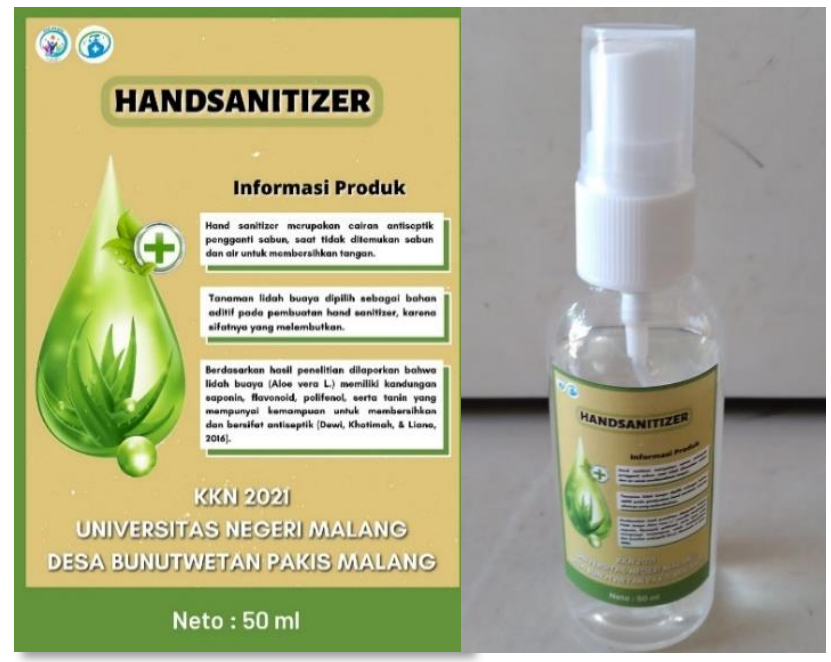

Gambar 1. Produk hand sanitizer KKN UM Desa Bunut Wetan

\section{HASIL DAN PEMBAHASAN}

Salah satu bahan baku pembuatan hand sanitizer merupakan etanol. Etanol merupakan senyawa yang terdiri dari dua atom karbon yang memiliki gugus $-\mathrm{OH}$ (hidroksil) yang termasuk dalam golongan alkohol primer. Etanol dengan kadar 60\% - 80\% dapat digunakan sebagai hand sanitizer karena bersifat antiseptik dan dapat membunuh kuman. Etanol dengan kadar tersebut memiliki kemampuan paling efektif dalam membunuh bakteri atau virus (Desiyanto \& Djannah, 2013). Sifat antimikroba dari alkohol didasarkan pada denaturasi protein. Alkohol tidak beracun dalam aplikasinya sebagai disinfektan tangan dan dinilai tidak memiliki potensi alergi (Lachenmeier, 2008). Penambahan bahan alami dapat dilakukan dalam pembuatan hand sanitizer.

Lidah buaya mengandung flavonoid, polifenol, saponin dan tanin yang bersifat antiseptik. Dalam getah lidah buaya terdapat kandungan vitamin A, E antioksidan, dan enzim yang dapat melembabkan kulit secara alami. Ekstrak lidah buaya dalam hand sanitizer dapat menyembuhkan luka karena kandungan-kandungan ini. Lidah buaya juga mengandung kalsium dan aktioksidan yang dapat memperkuat jaringan kulit. Kandungan vitamin $\mathrm{C}$ pada lidah buaya dapat menjaga kulit dari bakteri (Lusiana et al., 2020). Berdasarkan penelitian yang dilakukan oleh (Handayani, 2019) ekstrak hand sanitizer ekstrak lidah buaya dapat menghambat bakteri Staphylococcus aureus dan jamur Candida albicans. Pada penelitian (Susanty et al., 2020) uji mukroba paling efektif terhadap mengurangi bakteri escherichia coli 
pada tangan dengan menambahkan konsentrasi ekstrak lidah buaya sebanyak $7,5 \%$ pada hand sanitizer.

Desa Bunut Wetan merupakan salah satu desa terdampak pandemi covid-19. Berdasarkan wawancara dengan kepala Desa Bunut Wetan masyarakat masih memiliki kesadaran yang rendah tentang kesadaran penerapan protokol kesehatan yang dianjurkan oleh pemerintah. Protokol kesehatan yang dimaksud yaitu $5 \mathrm{M}$ diantaranya mencuci tangan atau memakai hand sanitizer, memakai masker, menjaga jarak, menjauhi kerumunan dan mengurangi mobilitas. Penekanan yang lebih kepada masyarakat Bunut Wetan tentang kesadaran mencuci tangan atau memakai hand sanitizer dan memakai masker. Hasil diskusi dengan skretaris desa melakukan sosialisasi pembuatan hand sanitizer kepada kader-kader posyandu. Tujuannya agar materi yang disampaikan pada saat sosialisasi dapat disebarkan kepada anggota posyandu yang lain sehingga pesan yang didapat bisa sampai ke masyarakat umum.

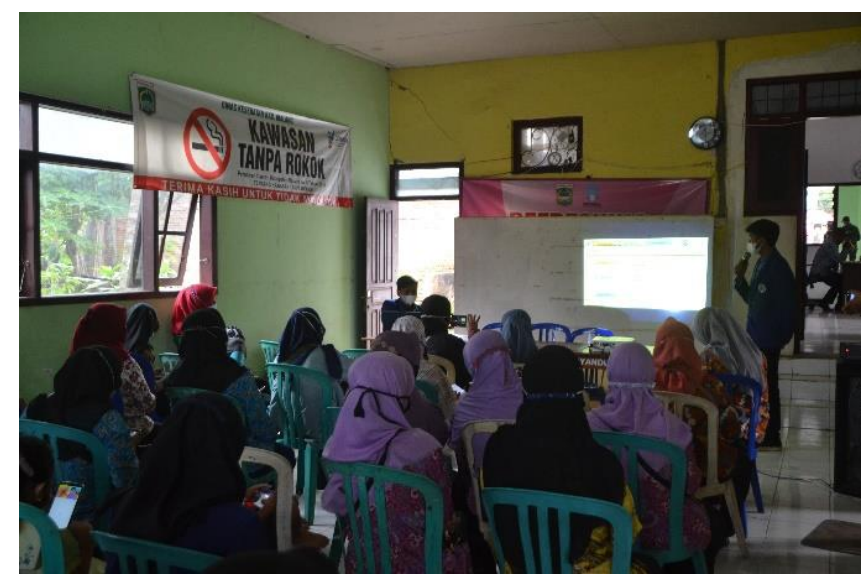

\section{Gambar 2. Pemaparan Materi Hand Sanitizer dan Lidah Buaya}

Gambar 2 merupakan pemaparan materi tentang hand sanitizer dan kebermanfaatan lidah buaya. Hand sanitizer lebih dikenalkan kepada masyarakat tentang bahan-bahan yang terdapat didalamnya. Hand sanitizer yang beredar dimasyarakat memilik dua jenis yaitu hand sanitizer gel dan hand sanitizer semprot. Hand sanitizer sangat fleksibel untuk dipakai ketika perjalanan. Selain dapat digunakan untuk membersihkan tangan juga dapat membersihkan benda lain seperti gadget. Pemaparan materi kebermanfaatan lidah buaya dilakukan dengan mengupas kandungan-kandungan lidah buaya kemudian menyampaikan manfaat dari kandungan yang ada. Tujuan penyampaian materi hand sanitizer agar masyarakat lebih paham tentang manfaat dan pentingnya memakai hand sanitizer selama pandemi covid-19 
untuk menjaga kebersihan tangan. Tujuan penyampaian materi lidah buaya agar masyarakat lebih bisa memanfaatkan lidah buaya. Di Desa Bunut Wetan lidah buaya hanya dikenal sebagai tanaman biasa yang sebenarnya dapat dimanfaatkan karena kandungannya.

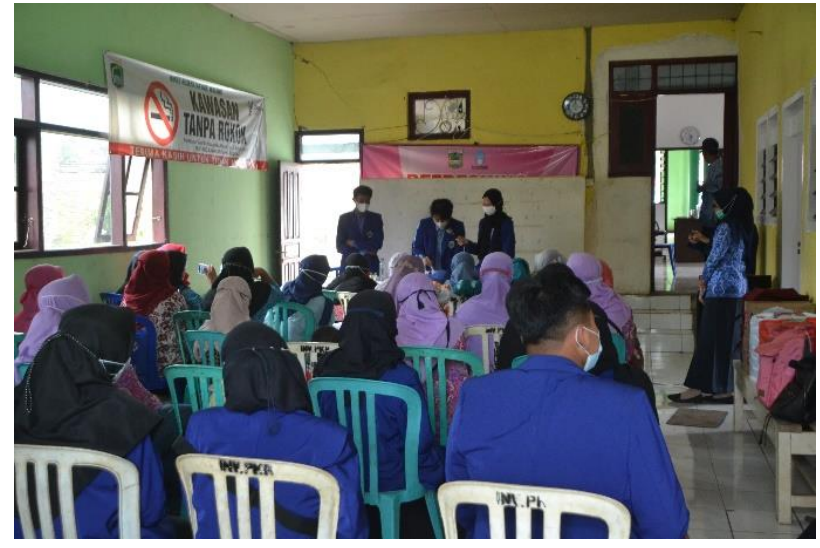

\section{Gambar 3. Demonstrasi Pembuatan Hand Sanitizer}

Gambar 3 merupakan demonstrasi pembuatan hand sanitizer yang dilakukan oleh tim KKN UM. Dalam acara demonstrasi ini peserta mengamati pembuatan hand sanitizer sesuai dengan takaran yang kemudian di kemas ke dalam botol semprot. Diinformasikan juga kepada peserta bahwa tidak hanya ekstrak lidah buaya saja yang dapat ditambahkan pada pembuatan hand sanitizer. Berbagai bahan alami dapat diekstrak untuk ditambahkan seperti ekstrak daun sirih, kemangi, kayu manis dan lainnya. Demonstrasi ini dilakukan untuk mengedukasi kader posyandu agar dapat membuat hand sanitizer secara mandiri. Terlebih lagi diharapkan bisa dimanfaatkan dan digunakan sendiri untuk mencukupi kebutuhan hand sanitizer di Desa Bunut Wetan.

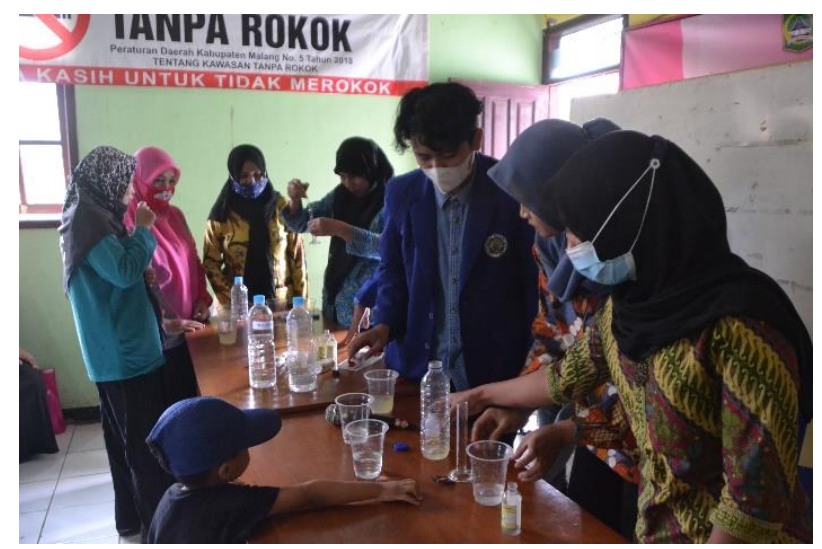

Gambar 4. Pendampingan Pembuatan Hand Sanitizer 
Gambar 4 adalah kegiatan pelatihan pembuatan hand sanitizer melalui pendampingan. Dua perwakilan dalam satu Rukun Warga (RW) maju ke depan untuk mendapatkan pelatihan secara bergantian. Pelatihan berjalan lancar dan berhasil dilakukan karena sebelumnya kaderkader posyandu telah melihat demonstrasi. Secara keseluruhan kader-kader posyandu sangat antusias dalam mengikuti demonstrasi dan pelatihan pembuatan hand sanitizer ekstrak lidah buaya.

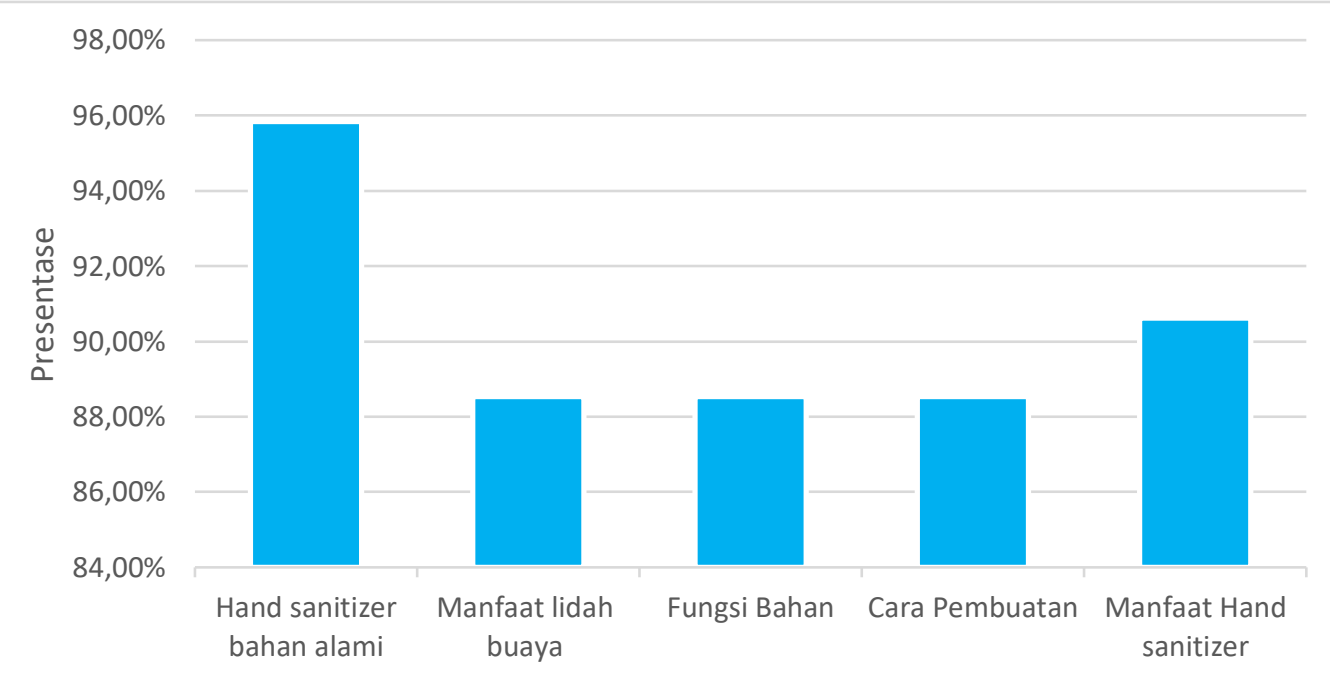

\section{Gambar 5. Hasil angket (\%) tingkat pemahaman ibu-ibu kader posyandu Desa Bunut Wetan terkait pembuatan hand sanitizer ekstrak lidah buaya}

Pada kegiatan akhir dilakukan pengisian angket yang digunakan untuk mengetahui tingkat pemahaman kader posyandu terkait pembuatan hand sanitizer ekstrak lidah buaya. Adapun hasil evaluasi diketahui bahwa dari 24 kader posyandu sebanyak 95,83\% paham bahwa hand sanitizer dapat dibuat dari bahan alami. Kemudian 88,54\% kader posyandu paham terkait manfaat lidah buaya dalam pembuatan hand sanitizer, fungsi dari bahan pembuatan hand sanitizer dan cara pembuatan hand sanitizer ekstrak lidah buaya. Serta 90,63\% kader posyandu paham mengenai manfaat hand sanitizer. Berdasarkan penelitian sebelumnya dari Angga (2020) menyatakan bahwa sebelum diadakan pelatihan pembuatan hand sanitizer, sebanyak $85,7 \%$ masyarakat paham terkait pembuatan hand sanitizer dari bahan alami. Kemudian setelah diadakan pelatihan pembuatan hand sanitizer, pemahaman masyarakat meningkat menjadi $100 \%$. Adanya tingkat pemahaman masyarakat yang tinggi, menunjukkan bahwa kegiatan sosialisasi pembuatan hand sanitizer dari bahan alami mampu 
untuk meningkatkan pemahaman dan kesadaran masyarakat terkait pentingnya menjaga kebersihan tangan sebagai salah satu tindakan preventif yang harus dilakukan di era pandemi.

\section{KESIMPULAN}

Hand sanitizer merupakan antiseptik yang dapat digunakan untuk membasmi kuman. Pembuatannya dapat menggunakan bahan-bahan sederhana seperti alkohol, gliserol dan ekstrak lidah buaya. Lidah buaya mengandung senyawa antibakteri yang digunakan untuk campuran handsanitizer dan senyawa lainnya yang bermanfaat untuk kulit. Adanya sosialisasi cara pembuatan handsanitizer dari ekstrak lidah buaya dapat membantu ibu-ibu Kader Posyandu di Desa Bunut Wetan Kecamatan Pakis Kabupaten Malang untuk membuat hand sanitizer sederhana di rumah. Kader-kader posyandu sangat antusias mengikuti sosialisasi. Berdasarkan hasil angket sebanyak 95,83\% kader paham bahwa hand sanitizer dapat dibuat dari bahan alami, sebesar $88,54 \%$ kader posyandu paham dengan manfaat lidah buaya dalam pembuatan hand sanitizer, fungsi dari bahan pembuatan hand sanitizer dan cara pembuatan hand sanitizer ekstrak lidah buaya. Serta $90,63 \%$ kader posyandu paham manfaat dari hand sanitizer. Saran untuk kegiatan pengabdian selanjutnya dapat lebih dipersiapkan peralatan yang digunakan untuk pelatihan yang dilakukan.

\section{DAFTAR PUSTAKA}

Desiyanto, F. A., \& Djannah, S. N. (2013). Efektivitas Mencuci Tangan Menggunakan Cairan Pembersih Tangan Antiseptik (Hand Sanitizer) Terhadap Jumlah Angka Kuman. Jurnal Kesehatan Masyarakat (Journal of Public Health), 7(2), 75-82. https://doi.org/10.12928/kesmas.v7i2.1041

Fatimah, C., \& Ardiani, R. (2018). Pembuatan Hand Sanitizer ( Pembersih Tangan Tanpa Air ) Menggunakan Antiseptik Bahan Alami. Prosiding Seminar Nasional Hasil Pengabdian, 336-343.

Handayani, G. N. (2019). Uji Aktivitas Ekstrak Etanol Daun Lidah Buaya (Aloe Vera) Terhadap Penghambatan Pertumbuhan Staphylococcus aureus Dan Candida albicans. Biosel: Biology Science and Education, 8(1), 1. https://doi.org/10.33477/bs.v8i1.841

Harjowinangun, M. D., Lusiana, R. A., Widodo, D. S., \& Suyanti, L. (2020). Edukasi Pembuatan Hand Sanitizer Berbasis Lidah Buaya pada. Jpkm Tabikpun, 1(1), 47-54. https://doi.org/10.23960/jpkmt.v1i1.19

Lachenmeier, D. W. (2008). Safety evaluation of topical applications of ethanol on the skin and inside the oral cavity. Journal of Occupational Medicine and Toxicology, 3(1), 1-16. https://doi.org/10.1186/1745-6673-3-26

Lusiana, R. A., Widodo, D. S., Suyanti, L., Gunawan, \& Abdul. (2020). Edukasi Pembuatan Hand Sanitizer Berbasis Lidah Buaya pada Masyarakat Desa Harjowinangun, Grobogan. JPKM TABIKPUN, 1(1), 47-54. https://doi.org/10.23960/jpkmt.v1i1.19 
Susanty, Hendrawati, T. Y., \& Rusanti, W. D. (2020). Pengaruh Penambahan Gel Aloe Vera Terhadap Efektifitas Antiseptik Gel. Jurnal Teknologi Universitas Muhammadiyah Jakarta, 6(2), 55-65.

Susilo, J., Erwiyani, A. R., \& Hati, A. K. (2013). Pembekalan Hand Hygiene Dan Pelatihan Pembuatan Hand Sanitizer Lidah Buaya (Aloe Vera L.) Di SMA Negeri 1 Ungaran Kabupaten Semarang. Indonesian Journal of Community Empowerment (IJCE), 11-20. 